\title{
ANALISIS FAKTOR PSIKOLOGIS DAN STRATEGI COPING STRES MAHASISWA MENIKAHPADA MASA PANDEMI COVID 19
}

\author{
Tien Asmara Palintan \\ Institut Agama Islam Negeri Parepare \\ tienasmarapalintan@iainpare.ac.id
}

\begin{abstract}
Currently, the number of married students in higher education is increasing from year to year. The roles played by students and housewives are very susceptible to causing stress for students. Interestingly, even though the COVID-19 pandemic is currently hitting, this has no impact on the student's decision-making process in getting married. This study aims to explore more deeply related psychological factors that influence student marriage decision making and find out the stress coping strategies developed by these students when facing pressure as a student with the status of being a wife and housewife. The research approach is qualitative phenomenology involving six students as research subjects. The data collection process was carried out by in-depth interviews and observation. The results of the study found that psychological factors that influenced student decision-making to marry during the COVID-19 pandemic were motivation, perception, learning, and attitude. Stress coping strategies developed by students to deal with the pressure (stress) they face are intropunitive, defensive, introversive, interactive, and impressive.
\end{abstract}

Keywords: psychological factors, stress coping, student married

\begin{abstract}
ABSTRAK
Saat ini jumlah mahasiswa menikah pada Perguruan Tinggi meningkat dari tahun ke tahun. Peran yang dijalani sebagai mahasiswa dan ibu rumah tangga sangat rentan menyebabkan stres bagi mahasiswa. Menariknya, meski saat ini pandemic COVID 19 sedang melanda, namun hal ini tidak berdampak pada proses pengambilan keputusan mahasiswa dalam melakukan pernikahan. Penelitian ini bertujuan untuk mengeksplorasi lebih dalam terkait faktor psikologis yang mempengaruhi pengambilan keputusan mahasiswa menikah dan mengetahui strategi copign stres yang dikembangkan mahasiswa tersebut ketika menghadapi tekanan sebagai seorang mahasiswa dengan status menjadi istri atau ibu rumah tangga. Pendekatan penelitian adalah kualitatif fenomenologi yang melibatkan enam orang mahasiswa sebagai subjek penelitian. Proses pengambilan data dilakukan dengan wawancara mendalam (in depth interview) dan observasi. Hasil penelitian menemukan faktor psikologis yang mempengaruhi pengambilan keputusan mahasiswa untuk menikah pada masa pandemic COVID 19 adalah motivasi, persepsi, belajar dadn sikap. Strategi coping stres yang dikembangkan mahasiswa untuk menghadapi tekanan (stres) yang dihadapi adalah intropunitive, defensivenes, intropersistive, interpersistive, dan Impersistive.
\end{abstract}

Kata Kunci: faktor psikologis, coping stres, mahasiswa menikah 


\section{PENDAHULUAN}

Pernikahan merupakan awal kehidupan rumah tangga dan terbentuknya keluarga sebagai kelompok sosial terkecil dalam masyarakat. Tujuan pernikahan adalah menciptakan suatu keluarga atau rumah tangga yang bahagia dan sejahtera (sakinah). Kebahagiaan dan kesejahteraan ini akan memberikan rasa aman, tentram dan puas bagi para anggotanya (Siahaan 2016). Namun bagaimana jika pernikahan tersebut dilaksanakan ditengah kondisi pandemi COVID-19? Saat ini, hampir di semua perguruan tinggi terdapat sejumlah mahasiswa yang sudah menikah. Kondisi pandemi COVID-19 yang melanda Indonesia ternyata tidak menyurutkan pengambilan keputusan mahasiswa dalam melaksanakan pernikahan. Bahkan fenomena pernikahan dini mengalami peningkatan selama masa pandemi COVID-19 (Republika.com 2019).

Pengambilan keputusan menikah yang dilakukan oleh mahasiswa merupakan hal menarik yang melibatkan aspek-aspek biologis, psikologis, sosiologis, religius, dan kultural kedua belah pihak (Rositoh, Sarjuningsih;, and Sa'adati 2017). Ada banyak faktor yang mempengaruhi, hasil penelitian yang dilakukan terkait pernikahan di kalangan mahasiswa S1 menyatakan bahwa mahasiswa menikah dengan motivasi takut dosa, ingin membahagiakan orang tua, perintah agama dan keyakinan bahwa menikah merupakan pilihan tepat bagi hidup (Anisaningtyas and Astuti 2018).

Namun apa yang terjadi apabila mahasiswa yang telah menikah tersebut dihadapkan dengan pilihan antara keluarga dengan dunia kampus? Melaksanakan peran sebagai mahasiswa semakin sulit jika disandingkan dengan peran lainnya. Konflik dalam menjalankan peran disebabkan berbagai hal, misalnya tekanan pada peran, keterbatasan waktu yang dimiliki mahasiswa, serta sulitnya menyesuaikan perubahan tingkah laku dari satu peran ke peran lainnya (Fristania 2021). Uniknya beberapa mahasiswa yang sudah membangun kehidupan keluarga justru mengaku menjadi pendorong cepat lulus dengan nilai tinggi, meski ada pula yang sebaliknya. Sebagian pula kebingungan dalam membagi waktu antara keluarga atau kuliah (Rachmah 2014). Tidak jarang hal tersebut dapat menyebabkan stres bagi mahasiswa tersebut.

Stres merupakan suatu keadaan tertekan baik secara fisik maupun secara psikologis (Chaplin 2002). Stres ditimbulkan dari tuntutan penyesuaian diri individu karena mengganggu kondisi keseimbangan individu (Azkiyati 2018). 
Berbagai sumber dapat menjadi pemicu stres pada mahasiswa yang telah menikah, baik dari lingkungan keluarga, konflik diri sendiri, dan kondisi kampus.

Mahasiswa yang berada dalam kondisi tertekan atau stres akan berada dalam situasi yang tidak nyaman. Kondisi ini membuat mahasiswa mengembangkan berbagai bentuk strategi agar dapat keluar darikondisi yang penuh tekanan tersebut. Coping stress merupakan reaksi terhadap tekanan yang berfungsi memecahkan dan mengurangi atau menggantikan kondisi yang penuh tekanan (Brown et al. 2020). Coping stress pada mahasiswa merupakan keterampilan menghadapi masalah berupa tekanan yang disebabkan oleh lingkungan internal dan eksternal (stressor) (Khairiyah, Kusuma 2017). Dengan strategi coping, mahasiswa mengelola stimulus yang dianggap bisa menimbulkan stres sehingga mahasiswa dapat beradaptasi dan kembali pada kondisi homeostatisnya (Rachmah 2014).

Faktor yang dapat menimbulkan stres yaitu faktor yang berhubungan dengan individu dan faktor yang berhubungan dengan situasi. Faktor yang berhubungan dengan pribadi individu, antara lain: pertama intelektualitas, individu yang memiliki intelektualitas rendah akan lebih rentan terhadap stres dibandingkan individu dengan tingkat intelektualitas yang diatasnya. Kedua, motivasi, individu dengan motivasi rendah cenderung lebih mudah ditimpa stres daripada individu dengan motivasi tinggi. Ketiga, karakteristik kepribadian, dimana individu dengan kepribadian tipe B lebih rentan terhadap stres dibandingkan individu dengan kepribadian tipe A (Sarafino 1998).

Mahasiswa merespon stres secara biologis dan secara psikososial. Secara individu, tahapan reaksi sebagai respon individu terhadap stres, antara lain: 1) Tahap peringatan merupakan reaksi yang alamiah, fungsi-fungsinya dipicu oleh sumber yang berasal dari dalam tubuh.;2) Tahap resisten merupakan tahap dimana individu menghadapi tekanan stresor yang sangat kuat, namun tidak sampai membuatnya meninggal.pada tahap ini, individu mampu beradaptasi dengan stressor; 3) Tahap kelelahan, tahap ini dimulai pada saat stres telah mencapai ambang batas miksimal. Jika stres berlanjut, biasanya timbul penyakit dan kerusakan organ internal serta dapat pula menyebabkan kematian (Prokop. CK 1991).

Adapun respon secara psikososial meliputi:1) Kognisi stres. Stres dapat mempengaruhi fungsi kognitif seseorang yang biasanya dapat terlihat dari kurangnya konsentrasi; 2) Emosi dan 
stres. Emosi cenderung memberi pengaruh terhadap terjadinya stres, dan pada umumnya manusia menggunakan emosi sebagai bentuk respon mereka terhadap stres yang dialami; 3) Perilaku sosial dan stres. Masalah-masalah dari lingkungan sosial bisa menjadi penyebab stres (Prokop. CK 1991). Faktor yang mempengaruhi coping stres pada mahasiswa meliputi: potensi dasar, maturitas. pendidikan, tipe kepribadian, sosial budaya dan lingkungan atau situasi (Rositoh et al. 2017).

Parek (Patnani, M., Ekowarni, E., dan Etsem 2002) menyatakan beberapa bentuk strategi coping yang diterapkan jika berada dalam kondisi penuh tekanan, antara lain: 1) Impunitive, strategi coping dimana individu menganggap bahwa tidak ada lagi yang bisa dilakukan dalam menghadapi kondisi yang penuh tekanan dari luar; 2) Intropunitive, yaitu tindakan menyalahkan diri sendiri untuk masalah yang dihadapi; 3) Ekstrpunitive, individu melakukan tindakan agresi untuk mengatasi masalahnya; 4) Defensiveness, individu melakukan pengingkaran atau rasionalisasi dalam mengatasi masalahnya; 5) Impersistive, individu merasa optimis bahwa waktu akan menyelesaikan masalah dan keadaan membaik kembali; 6) Intropersistive, individu percaya bahwa dia harus bertindak sendiri untuk mengatasi masalahnya; 7) Intrapersistive, individu megharapkan orang lain untuk menyelesaikan masalahnya; 8) Interpersistive, individu bahwa kerja sama antara dirinya dengan orang lain dapat mengatasi masalah yang dihadapinya.

Penelitian diharapkan mampu menggali secara spesifik faktor psikologis dan strategi coping stres yang dikembangkan mahasiswa yang telah menikah. Melalui penelitian ini diharapkan mampu memberi sumbangsih meliputi faktor psikologis pengambilan keputusan untuk menikah pada menikah, penyebab stres pada mahasiswa menikah, dan bagaimana mahasiswa menikah mengatasi stres yang dialami dengan peran ganda sebagai istri dan mahasiswa. Selain itu, hasil penelitian diharapkan mampu menjadi pertimbangan dalam menentukan kebijakan pada institusi Perguruan Tinggi untuk mendesain program bagi mahasiswa yang mampu memberi bekal agar mahasiswa dapat mengoptimalkan berbagai potensi yang dimiliki. Sehingga mahasiswa menikah yang rentan terpapar stres dapat meningkatkan kualitas kehidupannya dalam menjalankan peran sebagai civitas akademika. 


\section{METODE PENELITIAN}

Jenis penelitian yang digunakan adalah penelitian kualitatif dengan pendekatan fenomenologi. Dimana teknik pengumpulan data lebih banyak pada observasi dan wawancara mendalam (in depth interview). Setelah data terkumpul, peneliti melakukan reduksi data, penyajian dan verifikasi data. Keabsahan data dilakukan dengan keikutsertaan peneliti, pengamatan dan triangulasi data. Adapun objek dalam penelitian ini adalah faktor psikologis pengambilan keputusan mahasiswa untuk menikah dan strategi coping stres yang dikembangkan oleh mahasiswa menikah pada masa pandemi COVID-19.

Subjek dalam penelitian ini adalah mahasiswa Fakultas Tarbiyah IAIN Parepare dengan karakteristik sudah menikah dan pernikahannya dilaksanakan pada masa Pandemi COVID-19. Berikut gambaran subjek penelitian:

Tabel 1. Subjek Penelitian pengambilan keputusan. Mahasiswa adalah salah satu bagian dari pengambil keputusan (decision maker). Pengambilan keputusan pada mahasiswa untuk menikah pada umumnya dikaitkan dengan masalah dan tujuan (Alfaruqy, Putri, and Soedibyo 2021).Berdasarkan proses penelitian yang dilakukan, ditemukan beberapa faktor psikologis yang menyebabkan mahasiswa mengambil keputusan untuk menikah pada masa pandemic COVID -19, antara lain:

\section{Motivasi}

Merupakan berbagai motif yang menunjukkan alasan mengapa seseorang mau berbuat sesuatu. Motivasi adalah keadaan seseorang yang mendorongnya untuk melakukan suatu aktivitas terntentu untuk mencapai suatu tujuan (Suryabrata 2015). Hasil wawancara dengan subjek menyatakan bahwa motivasi mereka untuk menikah antara lain: menghindari fitnah dan terhindardari hubungan haram (subjek $\mathrm{RR}, \mathrm{YS})$

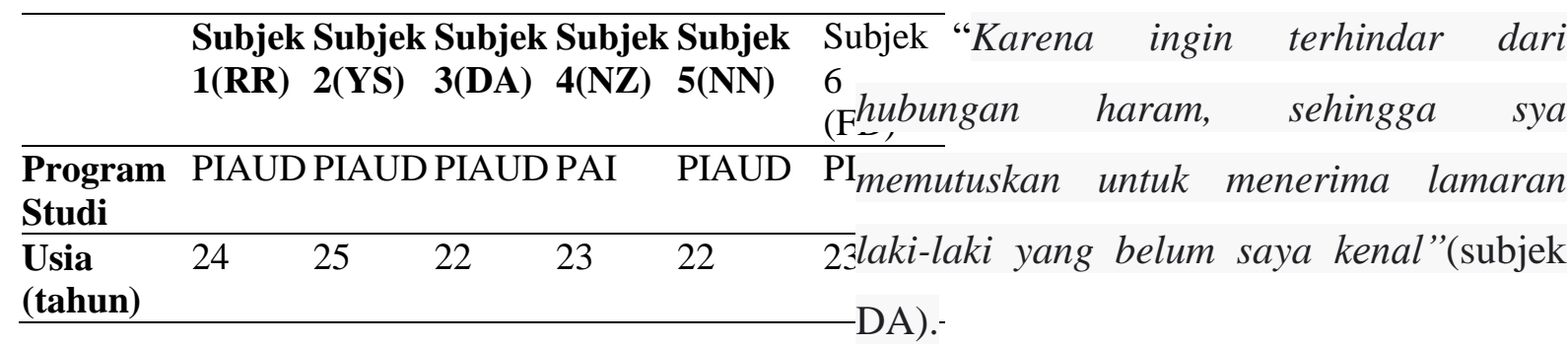

\section{HASIL DAN PEMBAHASAN}

Salah satu proses intelektual yang mendasari perilaku individu adalah
Motivasi lain karena menikah adalah cita-cita (Subjek NZ) dan bentuk ibadah seorangmuslimah (Subjek NN,FD).

"Diusia yang masih muda dengan 
status mahasiswa menikah bukan hanya untuk bahagia tetapi menikah untuk beribadah kepada Allah SWT. Jadi menurut saya pernikahan dengan status mahasiswa yah baik-baik saja" (Subjek NN).

\section{Persepsi}

Persepsi merupakan proses menginterpretasi dan mengorganisasi berbagai stimulus yang diterima oleh seseorang (Satrianingrum and Prasetyo 2020). Berbagai persepsi subjek tentang pernikahan sebelum mengambil keputusan untuk menikah, antara lain: menikah merupakan kewajiban untuk menghindari dosa.

"Persepsi tentang pernikahan dalam benak saya itu sebuah kewajiban dan semua orang wajib menikah untuk menghindari dosa." (subjek RR).

"Saya hanya berpikir saat setelah menikah saya terhindar dari perbuatan tidak baik (zina). Bukannya tidak bisa menjaga diri tapi ada baiknya jika ada yang mengajak serius maka kenapa menolak."(subjek DA).

Persepsi lainnya tentang menikah adalah proses penyatuan dua insan untuk saling menerima kelebihan dan kekurangan masing-masing (subjek YS,NN), pernikahan adalah dua insan yang berbeda di satukan dalam ikatan halal dan saling menerima kekurangan dan kelebihan masing-masing" (subjek YS).

"Pernikahan menyatu 2 insan menjadi 1. Pernikahan juga menjadi bagian dari misi ibadah kepada Allah SWT. Maka didalam pernikahan itu, supaya kita mampu melaksanakan visi ibadah kepada Allah SWT itu, yang kita cari adalah keberkahannya. Pernikahan juga merupakan ibadah terpanjang yang kita jalani." (subjek NN)

Menikah merupakan ibadah kepada Allah swt (subjek NZ,FD).

"Menurut persepsi saya menikah ialah sebuah ibadah yang tujuannya untuk menyempurnakan separuh agama. Karna dalam pernikahan apapun yang dilakukan dengan baik pasti yang baik pula yang akan didaptkan kelak akhirat."

\section{Stres pada Mahasiswa Menikah}

Stres merupakan kondisi dimana keadaan tubuh terganggu karena tekanan psikologis. Hal ini menyebabkan individu bereaksi terhadap stimulus yang mampu mengganggu keseimbangan (Rachmah 2014). Stres pada umumnya bersumber pada frustasi, konflik, tekanan dan krisis (Rositoh et al. 2017).

Hasil wawancara dengan subjek menyatakan bahwa terdapat beberapa hal 
yang menjadi penyebab terjadinya stres pada mahasiswa yang telah menikah, antara lain: 1) Frustasi, subjek merasakan frustasi karena belum bisa menyelesaikan studi tepat waktu dan belum bisa menjalankan peran yang baik sebagai istri (Subjek YS), dibatasi pergaulan dengan teman-teman kuliah dan berorganisasi (Subjek NN). Maramis (dalam Azkiyati 2018) menjelaskan bahwa frustasi disebabkan oleh adanya satu hal yang menghalangi pencapaian tujuan individu. 2) Konflik, terjadi apabila individu tidak mampu memilih antara dua atau lebih macam kebutuhan atau tujuan. Hasil wawancara dengan subjek menyatakan bahwa mereka lebih banyak mengalami konflik dengan diri sendiri dan juga keluarga. 3) Tekanan, terkait masalah penyesuaian. Dalam kehidupan sehari-hari, meski ada permasalahan namun jika dibiarkan bertumpuk maka dapat menjadi pencetus stres yang hebat; 4). Krisis, merupakan kondisi yang terjadi secara mendadak pada seorang individu. Terkait dengan krisis, semua subjek menyatakan bahwa krisis yang pernah mereka alami terkait dengan permasalahan financial keluarga (ekonomi). Pandemi menyebabkan suami subjek harus mencari pekerjaan baru (Subjek NN,RR, YS).

Stimulus yang mengganggu subjek, baik secara internal maupun eksternal dikenal dengan istilah stressor. Stimulus inilah yang menuntut dan membuat subjek melakukan respon adaptif. Ketika kemampuan adaptif subjek mengalami penurunan, maka rentan menyebabkan stres (Brownet al. 2020).

Stres direspon oleh individu secara biologis dan secara psikososial (Prokop. CK 1991). Respon secara biologis juga dirasakan oleh subjek sakit kepala (Subjek $\mathrm{NN}$ ), tidak bisa tidur badan semakin mengurus (Subjek YS). Adapun respon secara psikososial dapat meliputi kognisi stres yang berpengaruh pada fungsi kognitif seseorang yang biasanya dapat terlihat dari kurangnya konsentrasi.

"Kadang susah fokus dengan hal yang ingin Ssya kerjakan dan pekerjaan yang dilakukan tidak beres" (Subjek YS).

Respon psikososial lainnya yang dialami subjek terkait dengan masalah emosi. Respon ini cenderung memberi pengaruh terhadap terjadinya stres. Perasaan sedih, kebingungan dan berpikir yang tidak rasional menyebabkan subjek kesulitan makan, tidur, dan selalu menangis (Subjek DA,NZ). Kondisi psikis yang tidak stabil dapat menyebabkan perasaan tidak nyaman dan ketidakstabilan emosi. Hal tersebut menyebabkan subjek tidak mampu menjalankan perannya secara maksimal.

Beberapa sumber stres yang 
dirasakan oleh subjek penelitian menyebabkan mahasiswa berusaha mengatasi atau mengurangi tekanan yang dilakukan dengan beberapa bentuk strategi coping stres. Hasil wawancara yang dilakukan kepada subjek penelitian, ditemukan bahwa terdapat beberapa strategi coping yang digunakan subjek jika berada dalam kondisi penuh tekanan terangkum pada table 2 berikut:

Tabel 2. Strategi Coping Stres

\begin{tabular}{llll}
\hline Subjek & Coping Stres & Subjek & Coping Stres \\
\hline $\mathrm{RR}$ & Intropunitive & $\mathrm{NZ}$ & $\begin{array}{l}\text { Impersistive, } \\
\text { Intropunitive }\end{array}$ \\
\hline $\mathrm{YS}$ & & & Intropunitive, \\
& Defensivenes, & $\mathrm{NN}$ & Impersistive, \\
& & Intropunitive \\
& Intropersistive, & \\
& Interpersistive, \\
$\mathrm{DA}$ & Interpersistive, & $\mathrm{FD}$ & \\
& Intropunitive & & Interpersistive, \\
& &
\end{tabular}

Hasil di atas menunjukkan bahwa subjek menerapkan strategi coping yang berbeda dalam menghadapi tekanan yang ada, meski beberapa subjek mengembangkan strategi coping yang sama. Lazarus (Rachmah 2014) mengemukakan cara-cara yang dapat ditempuh ketika berada dalam situasi stres,yaitu: 1) Strategi coping yang berfokus pada masalah (problem focused coping), meliputi: aspek kehati-hatian, aspek tindakan instrumental, dan aspek negosiasi. 2) Strategi coping yang berfokus emosional (emotiona focused coping): meliputi aspek pelarian dari masalah, aspek pengurangan beban masalah, aspek menyalahkan diri sendiri, dan aspek pencarian arti hidup.

Problem focused coping merupakan upaya yang dilakukan mahasiswa untuk mengatasi tuntutan belajar pada Perguruan Tinggi berupa reaksi kognitif dan perilaku. Hal ini berdasarkan penilaian terhadap sumber coping yang dikembangkan oleh mahasiswa. Mahasiswa menyadari bahwa perasaan tidak nyaman dan timbulnya berbagai masalah akan muncul apabila mereka tidak segera menangani masalah tersebut. Sedangkan emotional focus coping merupakan upaya yang dilakukan mahasiswa untuk mengatasi tuntutan belajar dalam bentuk respon-respon emosi, baik positif maupun negatif.

\section{PENUTUP}

Hasil penelitian ini menunjukkan bahwa beberapa faktor psikologis yang mempengaruhi mahasiswa dalam pengambilan keputusan untuk menikah pada masa pandemic COVID 19 antara lain motivasi, persepsi, belajar dan sikap. Untuk mengurangi tekanan yang dirasakan selama melaksanakan peran 
ganda sebagai mahasiswa dan istri, mahasiswa mengembangkan beberapa bentuk coping stres pada dirinya. Adapun coping stres mahasiswa menikah tersebut antara

lain:

Intropunitive, defensivenes, intropersistive, , interpersistive, dan Impersistive.

Fokus analisis pada subjek penelitian ini adalah faktor psikologis yang mempengaruhi pengambilan keputusan menikah pada masa pandemi COVID 19 dan strategi coping stres mahasiswa menikah tersebut. Bagi para mahasiswa yang mengalami kondisi sama, dengan subjek penelitian, dapat menjadikan referensi dalam mengembangakan strategi coping untuk mengatasi permasalahan dalam menjalankan peran ganda. Sedangkan bagi peneliti selanjutnya diharapkan dapat menganalisis berbagai faktor lain yang mempengaruhi pengambilan keputusan mahasiswa dalam menikah serta menguraikan hubungan antara sumber stres dan coping stres mana yang paling berkontribusi dalam membantu mahasiswa menghadapi tekanan dalam hidupnya.

\section{DAFTAR PUSTAKA}

Alfaruqy, Muhammad Zulfa, Finda Kalina Putri, \& Sara Imanuel Soedibyo. (2021). Dinamika Psikologis Menikah Pada Masa
Pandemi COVID-19. Jurnal Psikologi TALENTA, Vol 6(2):55.

Anisaningtyas, Galuhpritta, \& Yulianti Dwi Astuti. (2018). Pernikahan Di Kalangan MahasiswaS-1. Proyeksi, Vol 6(2):21.

Azkiyati, Nurul. (2018). Wanita Menikah Yang Berprofesi. Proyeksi, Vol 6(1):59-71.

Brown, Samantha M., Jenalee R. Doom, Stephanie Lechuga-Peña, Sarah Enos Watamura, \& Tiffany Koppels. (2020). Stress and Parenting during the Global COVID-19 Pandemic. Child Abuse and Neglect 110.

Chaplin, J. (2002). Kamus Lengkap Psikologi. Jakarta: Raja Grafindo Persada.

Fristania, dika kalista. (2021). Keluarga Yang Baru Menikah Di Masa Pandemi.

Khairiyah, Nur, Farida Halis Dyah Kusuma, and Wahidyanti Rahayu H. (2017). Hubungan Peran Ganda Dengan Stres Pada Mahasiswa Program Studi Ilmu Keperawatan Tugas Belajar Di Universitas Tribhuwana Tunggadewi Malang. Journal Nursing News 2(3):31-37.

Patnani, M., Ekowarni, E., dan Etsem, MB. (2002). Kekerasan Fisil Terhadap Anak Dan Strategi Coping Yang Dikembangkan Anak. Indegenous VI (1):39.

Prokop. CK, dkk. (1991). Health Psychology, Clinical Methods and Research. New York: Mac Milan Publishing Company.

Rachmah, D. N. (2014). Sumber Stres Dan Coping Mahasiswa Pascasarjana. 
Prosiding Konferensi Nasional II Psikologi Kesehatan 107-19.

Republika.com. (2019). "BKKBN: 375

Remaja Menikah Dini Setiap Harinya | Republika Online.” Republika.Com.

Rositoh, Fajar., Sarjuningsih.,, \& Tatik Imadatus Sa'adati. (2017). Strategi Coping Stres Mahasiswi Yang Telah Menikah Dalam Menulis Tugas Akhir. Journal of Psychology and Islamic 1(2):5974.

Sarafino, EP. (1998). Health Psychology, Biopsychososial Interaction. New York: John Willey andSon Inc.

Satrianingrum, Arifah Prima, and Iis Prasetyo. (2020). Persepsi Guru Dampak Pandemi Covid-19 Terhadap Pelaksanaan Pembelajaran Daring Di PAUD. Jurnal Obsesi : Jurnal Pendidikan Anak Usia Dini 5(1):633.

Siahaan, Riana Friska. (2016). Membangun Keluarga Yang Sukses Dan Harmonis. Jurnal Keluarga Sehat Sejahtera 14(28):59-75.

Suryabrata, Sumadi. (2015). Psikologi Pendidikan. Jakarta: Raja Grafindo Persada. 